\title{
ANALISIS PENGESAHAN FAKTOR KERENTANAN PETANI PASCA TSUNAMI DI ACEH
}

\section{Determination Factors Analysis of Farmers Vulnerability Post Tsunami In Aceh}

\author{
Adhiana $^{1}$
}

\section{Email : adhiana2001@yahoo.com}

\begin{abstract}
Limitations of access and loss of various life assets caused by tsunamis and conflicts in Aceh faced by farmers have influenced their survival. The purpose of this research is to analyze the model of determination factor of farmer life assets the post-tsunami in Aceh. This study was conducted in Aceh Province covering five areas: Aceh Barat, Aceh Besar, Pidie Jaya, Bireun and Aceh Utara. The total sample for this study was 280 farmers using stratified random sampling method. This research uses primary data obtained by survey using quesioner and secondary data. Data analysis using qualitative and quantitative methods with Structural Equation Modeling model is by measurement model. This model 2 is used as the final model for the construct of the farmer's vulnerability factors as it demonstrates a good model compatibility. It also indicates that all loading factor values have above 0.5 and all probability values are significant at $\mathrm{a}=1 \%$. It indicated that all indicators can explain the existing constructs.
\end{abstract}

Key word: determination, vulnerability, farmer, post-tsunami, Aceh

\section{PENDAHULUAN}

Terdapat dua peristiwa yang menjadi momentum penting untuk membangun kembali perekonomian Aceh yang telah hancur akibat konflik yang berkepanjangan dan tsunami. Dua peristiwa tersebut yaitu bencana alam tsunami pada Desember 2004 dan penandatanganaan Nota Kesefahaman (MoU- Memory of Understanding) antara Pemerintah Republik Indonesia dan Gerakan Aceh Merdeka (GAM) pada tanggal 15 Agustus 2005. Peristiwa itu juga merupakan salah satu bentuk kerentanan yang bersifat guncangan karena telah merusak struktur kehidupan dan perekonomian serta kelestarian hidup masyarakat

Aceh pasca konflik dan tsunami telah dihadapkan kepada kondisi yang parah mengenai kemiskinan. Meskipun pada tahun 2016 tingkat kemiskinan di Aceh telah menurun menjadi 17,72 persen tetapi tetap jauh lebih tinggi jika dibandingkan wilayah-wilayah lain di Indonesia (Aceh Dalam Angka 2015). Sebahagian besar penduduk miskin berada di daerah perdesaan, dan hampir 70 persen dari mereka mempunyai pekerjaan utama sebagai petani. Sektor pertanian menyerap tenaga kerja terbesar, iaitu sebesar 48,49 persen daripada jumlah angkatan kerja yang

\footnotetext{
${ }^{1}$ Staf Pengajar di Prodi Agribisnis Fakultas Pertanian Universitas Malikussaleh
} 
berjumlah 1978 987orang (Aceh dalam Angka, 2015). Selain itu sebanyak 70 persen rumah tangga di perdesaan umumnya bergantung kepada sektor pertanian. Namun setelah melalui masa darurat, masa rehabilitasi dan rekonstruksi hampir 10 tahun dengan menghabiskan bajet triliunan rupiah telah banyak hal yang dilakukan terutama di bidang rehabilitasi seperti: pembangunan perumahan penduduk yang terkena dampak tsunami, pembangunan infra-struktur publik, dan perbaikan di bidang perekonomian masyarakat (livelihood). Pemulihan di sektor pertanian dan perikanan misalnya telah menyebabkan potensi perikanan dan pertanian di Aceh mengalami berbagai peningkatan pada beberapa aspek. Meskipun dampaknya terhadap pemulihan ekonomi masyarakat secara lebih luas belum cukup signifikan dan belum mampu memberikan kekuatan dan peran yang lebih kuat terhadap pertumbuhan perekonomian dan peningkatan pendapatan dan kesejahteraan serta kelestarian kehidupan masyarakat. (Agussabti, et.al. 2010).

Kehidupan masyarakat dapat dikatakan berkelanjutan (sustainable) apabila mereka mampu mengatasi dan menghadapi berbagai bentuk kerentanan yang ada. Artinya ia mampu mengatasi berbagai perubahan (trends), tekanan dan goncangan (shocks), serta perubahan musiman (seasonality) yang setiap saat mungkin terjadi, serta mempertahankan kemampuan dan sumber daya yang telah ada ataupun meningkatkannya untuk masa sekarang dan masa depan tanpa merusak sumber daya alam yang ada (DFID, 1999 dan FAO, 2000). Namun pada kenyataannya hingga saat ini masih banyak masyarakat Aceh yang hidup di perdesaan belum mampu mengatasi dan menghadapi berbagai bentuk kerentanan yang ada, sehingga mereka masih terbelenggu dalam kemiskinan.

Kerentanan adalah keadaan yang mudah sakit ataupun mudah jatuh kepada kesusahan (Kamus Dewan Edisi IV). Kerentanan adalah karakteristik spesifik atau kondisi yang akan meningkatkan kemungkinan bencana yang akan mengakibatkan kerosakan, kerugian, dan kehilangan. Kadar kerentanan bervariasi dan bergantung daripada karakteristik (exposure) seperti reka bentuk bangunan, bahan pembinaan, demografi, lokasi, dan lainlain (Noson 2000). Ruhiyat, E. (2012) dan ISDR (2004) menambahkan bahawa kerentanan (vulnerability) adalah sekumpulan keadaan atau suatu akibat daripada keadaan (faktor fizikal, sosial, ekonomi dan alam sekitar) yang berpengaruh buruk terhadap upaya pencegahan bencana. Terdapat beberapa jenis kerentanan, iaitu :

i. Kerentanan fisik, yaitu merangkum kondisi fisik bangunan (lokasi, kualitas, pembangunan gedung \& infrastruktur).

ii. Kerentanan sosial, yaitu merangkum kondisi penduduk, jumlah dan besaran (pertumbuhan populasi), kualitas hidup, pola budaya, perilaku (pendidikan, status, gender,minoritas.

iii.Kerentanan ekonomi, yaitu merangkum kegiatan ekonomi (pertanian monokultur, perbankan, keuangan), tingkat kesejahteraan (status ekonomi, kemiskinan, kerentanan bahan makanan, kurang akses terhadap air, listrik, kesehatan, pengangkutan).

iv. Kerentanan lingkungan alam sekitar, yaitu merangkumi kondisi fizikal alam (pemotongan hutan, penurunan kualitas tanah, terganggu ekosistem) (Ruhiyat, E. 2012).

Kerentanan adalah kondisi atau karakteristik biologis, geografi, sosial, 
ekonomi, politik, budaya dan teknologi suatu masyarakat di suatu wilayah untuk jangka waktu tertentu yang mengurangi kemampuan masyarakat tersebut untuk mencegah, serta mencapai kesiapan dan menghadapi impak bahaya tertentu. Masyarakat miskin yang tinggal di kawasan rawan gempa bumi adalah lebih rentan daripada mereka yang lebih sejahtera dan tinggal di kawasan yang sama, kerana masyarakat miskin pada umumnya tidak mampu membangun tempat tinggal dengan konstruksi yang aman terhadap gempa (ISDR 2004)).

Konteks

kerentanan (vulnerability contexts) meliputi lingkungan eksternal dan internal yang meliputi kehidupan setiap individu dan keluarga serta masyarakat. Di mana keadaan yang sering dihadapi menunjukkan bahwa tersedianya sumberdaya yang melimpah dalam masyarakat tidak selalu memberikan kehidupan yang lebih baik bagi warganya. Sebaliknya, suatu keadaan masyarakat dimana sumberdaya yang tersedia adalah terbatas, namun warganya mampu mencapai kehidupan yang memadai (Serrat, O. 2008). Hal ini disebabkan kerana ada faktor-faktor lain yang turut mempengaruhi kelestarian kehidupan masyarakat, iaitu konteks kerentanan.

Kerentanan dapat digambarkan sebagai keadaan yang setiap saat dapat berubah/ mempengaruhi keadaan kehidupan masyarakat. Setiap masyarakat memiliki bentuk dan kecenderungan kerentanan yang berbeza, sesuai dengan keadaan sekitar dan perubahan masyarakat itu sendiri. Kerentanan pula merupakan aspek yang sangat penting untuk diperhatikan dalam merencanakan suatu kebijakan atau program kegiatan dalam upaya mewujudkan kehidupan yang lebih baik. Banyak program pembangunan yang dilaksanakan tidak mencapai manfaat yang optimal atau bahkan mengalami kegagalan kearena tidak memperhitungkan kerentanan yang ada.

Keterbatasan akses dan sumberdaya kehidupan merupakan salahsatu masalah kerentanan yang dihadapi oleh masyarakat miskin yang sebagian besar berada di wilayah pedesaan. Selain pendidikan yang rendah dan kebijakan pembangunan yang kurang berpihak pada masyarakat miskin juga mengakibatkan mereka terpinggir dan tiada kesempatan untuk turut mengambil keputusan dalam pengaturan sumberdaya. Keadaan demikian seringkali diperburuk dengan keadaan alam yang kurang menguntungkan serta ancaman pelbagai wabah penyakit mahupun bencana alam yang boleh datang setiap saat. Kerentanan dan ancaman bencana alam (seperti gempa bumi dan tsunami) dan ketimpangan sosial, secara umum masih menjadi ancaman yang menyelimuti sebahagian besar kehidupan masyarakat. Untuk mengatasi kerentanan diperlukan peningkatan peran dan fungsi sosial masyarakat dalam proses politik, termasuk kaum wanita selain juga meningkatkan akses pemilikan sumber daya (Evy Lisna et al. 2012).

Manakala kerentanan sosial ekonomi pula ditakrifkan sebagai keterpaparan terhadap segala kemungkinan tekanan dan kesukaran yang akan dihadapi populasi dari sisi sosioekonomi berupa kemungkinan kehilangan dan kerugian yang dialami saat bencana terjadi, penerimaan dan pemulihan setelah bencana terjadi, aspek pendidikan, keamanan, sistem pemerintahan, pengetahuan dan lainlain. Dari teori Masozera menyatakan bahawa kelompok dengan kerentanan yang lebih tinggi termasuk kaum minoritias perempuan-kepala rumah tangga, orang tua, para pengangguran, 
buta huruf atau tidak berpendidikan, dan yang sakit atau cacat yang paling rentan terhadap bencana. Selain itu, kurangnya akses terhadap ilmu pengetahuan, ekonomi, atau sumber daya manusia juga dapat mengurangi kapasiti beberapa kelompok sosial-ekonomi untuk menghadapi bencana (Masozera et al. 2006).

Hubungan antara status kemiskinan sebuah rumah tangga dengan kerentanan juga dapat diidentifikasi. Kumala (2014) menemukan bahwa hubungan antara status kemiskinan rumah tangga dengan kerentanan di Pulau Jawa (2008-2010) menunjukkan corak yang sama, yaitu apabila sebuah rumah tangga berstatus miskin, maka kecenderungannya menjadi rentan lebih besar berbanding rumah tangga yang tidak miskin. Di daerah perkotaan dan pedesaan, rumah tangga yang miskin lebih rentan terhadap kemiskinan berbanding rumah tangga yang tidak miskin. Pendapat ini didukung oleh (Chaudhuri et al. 2008) yang menyimpulkan bahawa rumah tangga yang rentan miskin adalah rumah tangga yang memiliki peluang tinggi untuk jatuh miskin pada masa yang akan datang. Dengan demikian, rumah tangga yang rentan miskin merupakan rumah tangga yang diprediksi menjadi miskin pada tahun depan.

Dalam penelitian ini kerentanan yang dikaji merangkum faktor yang diakibatkan oleh tsunami dan konflik dan masyarakat Aceh juga mengalami bentuk kerentanan yang berbeda dengan masyarakat di daerah lainnya. Oleh sebab itu dirasa perlu untuk menganalisis pengesahan faktor keretanan petani pasca tsunami di Aceh dengan menggunakan model SEM yaitu dengan model pengukuran (measurement model). Tujuan penelitian ini adalah untuk menganalisis pengesahan factor kerentanan petani pasca tsunami di Aceh.

\section{METODE PENELITIAN}

\section{Populasi dan Jenis Data}

Populasi penelitian ini adalah petani di Aceh pasca tsunami yang meliputi lima kabupaten yaitu Kabupaten Aceh Barat, Aceh Besar, Pidie Jaya, Bireun dan Aceh Utara. Pengambilan sampel dilakukan secara purposive (sengaja), dan jumlah sampel adalah 280 petani. Penelitian ini dilaksanakan dari bulan Maret hingga Desember 2015. Jenis data yang digunakan adalah data kualitatif dan kuantitatif, dan sumber data adalah data primer dan data sekunder. Data primer merupakan data cross-section yang dikumpulkan melalui hasil observasi langsung dan wawancara yang dilakukan dengan menggunakan kuesioner pada petani di daerah penelitian dan data sekunder yang diperoleh dari instansi terkait.

\section{Analisis Data}

Alat analisis yang digunakan untuk penelitian ini adalah model pengesahan faktor (Confirmatory Factor Analysis (CFA) yang terdapat dalam SEM. Analisis pengesahan faktor (CFA) ini digunakan untuk menguji model pengukuran (measurement model) (Hair et al. 2006). Dengan analisis ini akan diketahui apakah indikator-indikator yang ada dapat menjelaskan sebuah konstruk ( Santoso, S. 2012). Analisis ini akan dilaksanakan untuk menguji setiap dimensi variabel aset yang telah diketahui berdasarkan dari penelitianpenelitian terdahulu. Metode maximum likelihood digunakan untuk mengestimasi $\quad 10$ indikator dari dua konstruk kerentanan yang dibentuk. Gambar 2 menunjukkan model 
pengesahan faktor untuk faktor

kerentanan.

Analisis data dilakukan dengan menggunakan model penentuan (Measurement Model) yang terdapat dalam Structural Equation Modeling (SEM). Model penentuan ataupun dikenal sebagai model analisis pengesahan faktor (CFA) merupakan satu proses yang membolehkan peneliti menggunakan beberapa indikator untuk mendapatkan satu variabel laten eksogen (independen) ataupun variabel endogen (dependen) yang dinamakan sebagai latent factor ataupun latent construct. Setiap variabel laten mempunyai berbagai ukuran atau indikator. Pemilihan indikator dan penentuan setiap faktor laten dibuat berdasarkan teori ataupun kajian-kajian yang dilakukan sebelum ini. Dengan model CFA ini, maka terlebih dahulu peneliti harus menentukan jumlah faktor yang dikehendaki dalam satu set variabel laten dan di dalam faktor yang manakah setiap indikator ini akan dimasukkan sebelum menjalankan analisis. CFA akan menunjukkan sejauh mana spesifikasi faktor yang diramalkan oleh peneliti sesuai dengan realitas yang sebenar. Dengan kata lain CFA merupakan alat yang membolehkan kita menerima ataupun menolak teori yang ada sebelumnya.

Dalam bentuk persamaan, teori pengesahan faktor boleh diwakili oleh beberapa persamaan seperti berikut : $x_{1}=\lambda_{\mathrm{x} 11} \xi_{1}+\delta_{1}$

(1.1)

$x_{2}=\lambda_{\mathrm{x} 22} \xi_{2}+\delta_{2}$

$$
x_{n}=\lambda_{\mathrm{xn}, \mathrm{n}} \xi_{\mathrm{n}}+\delta_{\mathrm{n}}
$$

Di mana,

$x_{1} \ldots . x_{n}=$ indikator yang menentukan construct

$\xi_{1} \ldots \xi_{\mathrm{n}}=$ konstruk yang ditentukan oleh indikator $\mathrm{x}$

$\lambda_{\mathrm{x} 11}=$ 'path' yang mewakili hubungan antara faktor laten $\left(\xi_{1}\right)$ dan

$\delta \quad=$ eror term

Model penentuan ini meliputi konstruk yang tiada hubungan sebab akibat dan korelasi di antara mereka. Model ini

hanya menghitung estimasi covariant dengan menggunakan persamaan yang mewakili teori yang akan diuji. Matriks covarian ini kemudian dibandingkan dengan matriks covarian yang sebenar yang dihitung daripada data indikator. Model penentuan ini dikatakan sepadan apabila kedua-dua matriks covarian adalah hampir sama. Variabel laten dihubungkan dengan indikator melalui model pengukuran yang berbentuk analisis faktor. Setiap variabel laten dimodelkan sebagai sebuah faktor yang mendasari indikator terkait ( Andriani, D. 2013). Muatan faktor (factor loading) yang menghubungkan variabel laten dengan indikator yang dapat diketahui diberi label $\lambda$ ("lambda"). Error dalam model pengukuran dinotasikan dengan $\xi$ (ksi). Model pengukuran dapat digambarkan pada Gambar 1. 


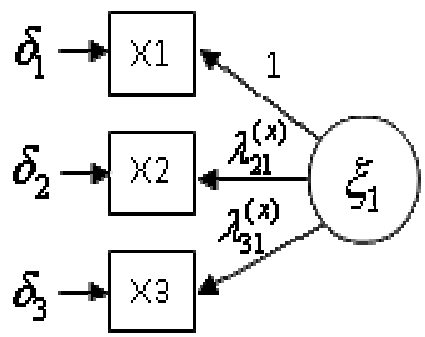

Gambar 1. Model Pengukuran SEM

Pada penelitian ini menggunakan 2 faktor laten yaitu kerentanan akibat tsunami dan konflik yang dihadapi oleh petani, yaitu dapat dilihat pada Gambar 2 di bawah.

\section{Model Pengesahan Faktor untuk Variabel Kerentanan}

Model pengesahan faktor untuk variabel kerentanan adalah seperti berikut. Dalam kajian ini, kerentanan $\left(Z_{1}\right)$ dipengaruhi oleh dua indikator utama iaitu konflik (Kfk) dan tsunami (Tsm), di mana konflik dan tsunami dipengaruhi oleh masing-masing lima indicator.

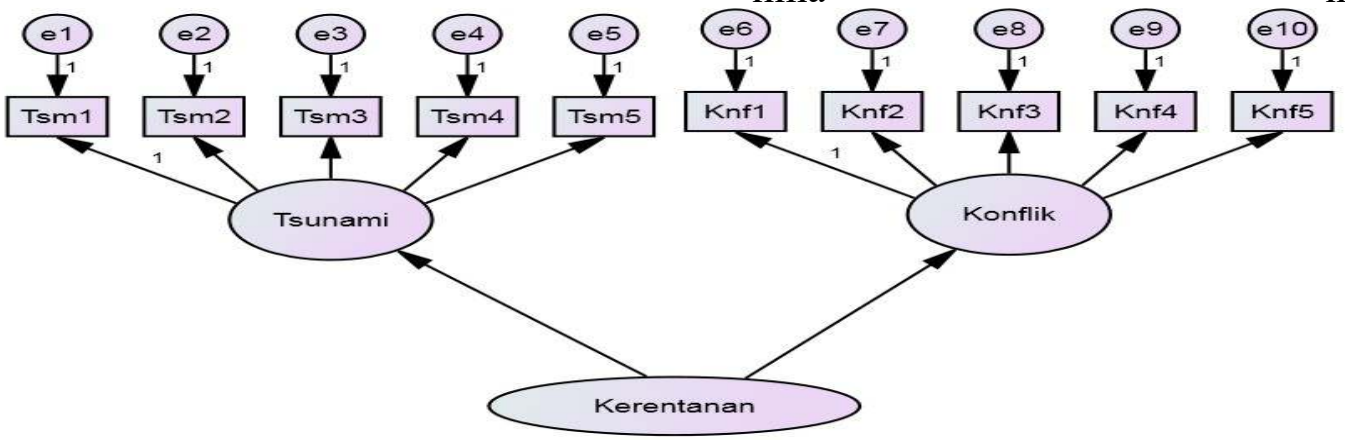

Rajah 4.10 Hipotesis model penentu untuk faktor kerentanan

\section{a. Tsunami (Tsm)}

Model penentuan untuk faktor tsunami adalah seperti berikut. Dalam kajian ini, faktor tsunami dipengaruhi oleh lima indikator iaitu $\mathrm{Tsm}_{1}, \mathrm{Tsm}_{2}, \mathrm{Tsm}_{3}, \mathrm{Tsm}_{4}$ dan
Tsm5. Gambar 2 menunjukkan bahawa variabel $\mathrm{Tsm}_{1}, \mathrm{Tsm}_{2}, \mathrm{Tsm}_{3}, \mathrm{Tsm}_{4}$ dan $\mathrm{Tsm}_{5}$ tergantung kepada variabel latent (Tsm ) dan eror term penentuan et 1 , et 2 , et 3 , et dan $_{5}$ et 5 .

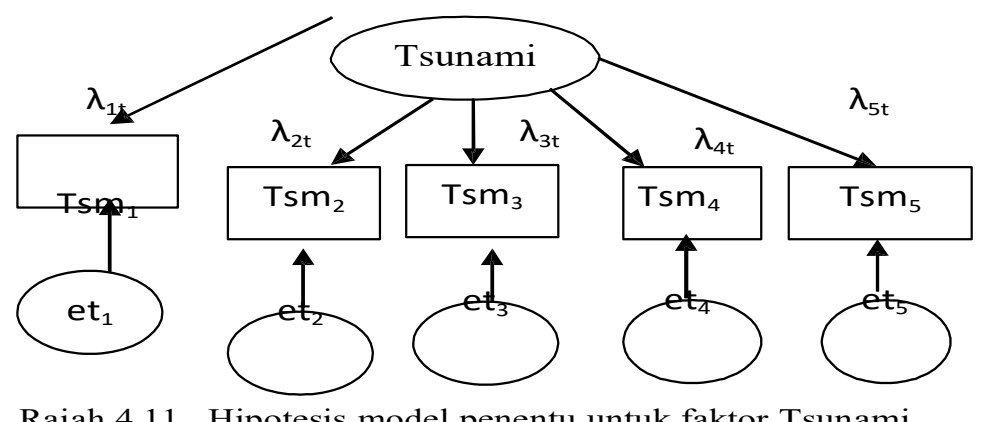

Rajah 4.11 Hipotesis model penentu untuk faktor Tsunami 
Secara persamaan matematik, model ini boleh ditulis seperti berikut :

$$
\begin{aligned}
& \mathrm{Tsm}_{1}=\lambda_{1 \mathrm{t}} \mathrm{T}+\mathrm{et}_{1} \\
& \mathrm{Tsm}_{2}=\lambda_{2 \mathrm{t}} \mathrm{T}+\mathrm{et}_{2} \\
& \mathrm{Tsm}_{3}=\lambda_{3 \mathrm{t}} \mathrm{T}+\mathrm{et}_{3} \\
& \mathrm{Tsm}_{4}=\lambda_{4 \mathrm{t}} \mathrm{T}+\mathrm{et}_{4} \\
& \mathrm{Tsm}_{5}=\lambda_{5 \mathrm{t}} \mathrm{T}+\mathrm{et}_{5}
\end{aligned}
$$

Di mana,

$\mathrm{Tsm}_{1}=$ Persepsi petani mengenai kehilangan peralatan untuk bekerja semasa tsunami

$\mathrm{Tsm}_{2}=$ Persepsi petani mengenai kehancuran infrastruktur

$\mathrm{Tsm}_{3}=$ Persepsi petani/nelayan mengenai kemudahan mendapatkan bantuan modal kewangan

$\mathrm{Tsm}_{4}=$ Persepsi petani mengenai trauma yang dihadapi
$\mathrm{Tsm}_{5}=$ Persepsi petani mengenai kehilangan pemilikan atas tanah yang dimiliki

Tsm=variabel laten untuk faktor tsunami

$\lambda_{1 \mathrm{t}}-\lambda_{5 \mathrm{t}}=$ Koefisien yang menjelaskan pengaruh variabel faktor tsunami terhadap indikator $\mathrm{Ts}_{1}, \mathrm{Ts}_{2}, \mathrm{Ts}_{3}, \mathrm{Ts}_{4}$ dan $\mathrm{Ts}_{5}$

$\mathrm{e}_{1}, \mathrm{e}_{2}, \mathrm{e}_{3}, \mathrm{e}_{4}, \mathrm{e}_{5}=$ eror term untuk indikator $\mathrm{Tsm}_{1}, \mathrm{Tsm}_{2}, \mathrm{Tsm}_{3}, \mathrm{Tsm}_{4}$ dan Tsm5.

\section{Konflik (Kfk)}

Model penentuan untuk faktor konflik adalah seperti berikut. Dalam penelitian ini, konflik dipengaruhi oleh lima indikator iaitu $\mathrm{Kfk}_{1}, \mathrm{Kfk}_{2}, \mathrm{Kfk}_{3}$, $\mathrm{Kfk}_{4}$ dan $\mathrm{Kfk}_{5}$. Gambar 3 menunjukkan bahwa variabel $\mathrm{Kn}_{1}, \mathrm{Kn}_{2}, \mathrm{Kn}_{3}, \mathrm{Kn}_{4}$ dan $\mathrm{Kn}_{5}$ vektor penentuan $\mathrm{e}_{6}, \quad \mathrm{e}_{7}, \mathrm{e}_{8}, \mathrm{e}_{9}$ dan $\mathrm{e}_{10}$.

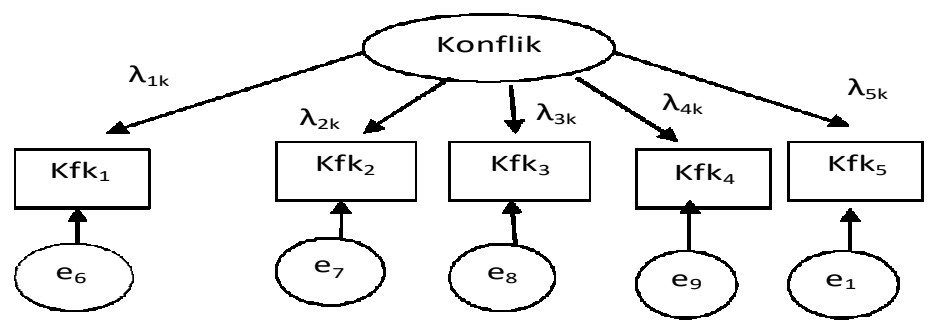

Rajah 4.12 Hipotesis model penentu untuk faktor Konflik

Secara persamaan matematik, model ini boleh ditulis seperti berikut :

$\mathrm{Kfk}_{1}=\lambda_{1 \mathrm{k}} \mathrm{K}+\mathrm{e}_{6}$

$\mathrm{Kfk}_{2}=\lambda_{2 \mathrm{tk}} \mathrm{K}+\mathrm{e}_{7}$

$\mathrm{Kfk}_{3}=\lambda_{3 \mathrm{k}} \mathrm{K}+\mathrm{e}_{8}$

$\mathrm{Kfk}_{4}=\lambda_{4 \mathrm{k}} \mathrm{K}+\mathrm{e}_{9}$

$\mathrm{Kfk}_{5}=\lambda_{5 \mathrm{k}} \mathrm{K}+\mathrm{e}_{10}$

Di mana,

$\mathrm{Kfk}_{1}=$ Persepsi petani mengenai kehilangan peluang pekerjaan

$\mathrm{Kfk}_{2}=$ Persepsi petani mengenai kehilangan harta benda

$\mathrm{Kfk}_{3} \quad=$ Persepsi petani mengenai potensi munculnya konflik baru

$\mathrm{Kfk}_{4} \quad=$ Persepsi petani mengenai trauma akibat konflik

$\mathrm{Kfk}_{5} \quad=$ Persepsi petani mengenai kemudahan memasarkan hasil pertanian

Kfk =Variabel laten untuk faktor konflik $\lambda_{1 \mathrm{k}}-\lambda_{5 \mathrm{k}}=$ Koefisien yang menjelaskan pengaruh variabel konflik terhadap indikator $\mathrm{Kfk}_{1}$, $\mathrm{Kfk}_{2}$, $\mathrm{Kfk}_{3}, \mathrm{Kfk}_{4}$ dan $\mathrm{Kfk}_{5}$

$\mathrm{e}_{6}, \mathrm{e}_{7}, \mathrm{e}_{8}, \mathrm{e}_{9}$ dan $\mathrm{e}_{10}=$ error term untuk indikator $\mathrm{Kfk}_{1}, \mathrm{Kfk}_{2}$, $\mathrm{Kfk}_{3}, \mathrm{Kfk}_{4}$ dan Kfk .

\section{ANALISIS PENGESAHAN FAKTOR VARIABEL KERENTANAN}

Terdapat berbagai indikator yang mewakili setiap faktor kerentanan. Faktor kerentanan ini merangkum dua faktor yaitu tsunami dan konflik. Analisis pengesahan faktor (MPF) akan dilaksanakan bagi menguji setiap dimensi variabel faktor kerentanan yang telah diketahui berdasarkan dari kajian-kajian yang lalu. Metode estimasi menggunanakan maximum likelihood untuk mengestimasi 10 indikator dari dua 
konstruk faktor kerentanan yang dibentuk.

Gambar 4 menunjukkan hipotesis model 1 pengesahan faktor untuk faktor kerentanan.

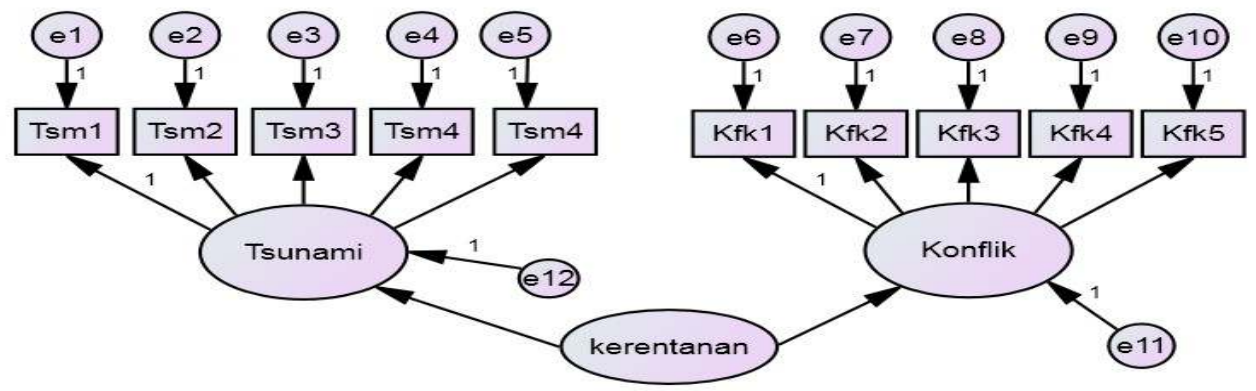

Rajah 6.3 Model 1 pengesahan faktor kerentanan

Hasil analisis pada model 1 mendapatkan bahwa nilai $\chi^{2}$ (CMIN) 136.038 dengan darjah kebebasan sebanyak 34 dan nilai probilitas 0.000 telah menghasilkan CMIN/DF sebanyak 4.001 yaitu melebihi satu dan kurang dari 5 seperti yang disarankan oleh banyak penulis mengenai aspek kesepadanan model dalam model pengesahan faktor. Nilai kebanyakan indeks kesepadanan model belum mencapai tahap kesepadanan model yang minimum $(\mathrm{GFI}=0.953$, AGFI $=0.923, \mathrm{CFI}=0.927, \mathrm{NFI}=0.906, \mathrm{IFI}=$ 0.928, $\mathrm{TLI}=0.904$, RMSEA $=0.074)$.
Hasil ini menunjukkan kesepadanan data dengan model yang di hipotesis adalah baik. Namun model ini mendapatkan pemboleh ubah tsm1 dan tsm5 mempunyai nilai koefisien yang rendah yaitu 0.228 dan 0.234 , manakala variabel kfk1 mempunyai nilai yang rendah dan negatif iaitu -.179. Bagi memperoleh kesepadanan model yang baik, oleh sebab itu model ini akan dianggarkan semula dengan menghilangkan pemboleh ubah tsm1, tsm5 dan kfkl dan dinamakan model 2 (Gambar5).

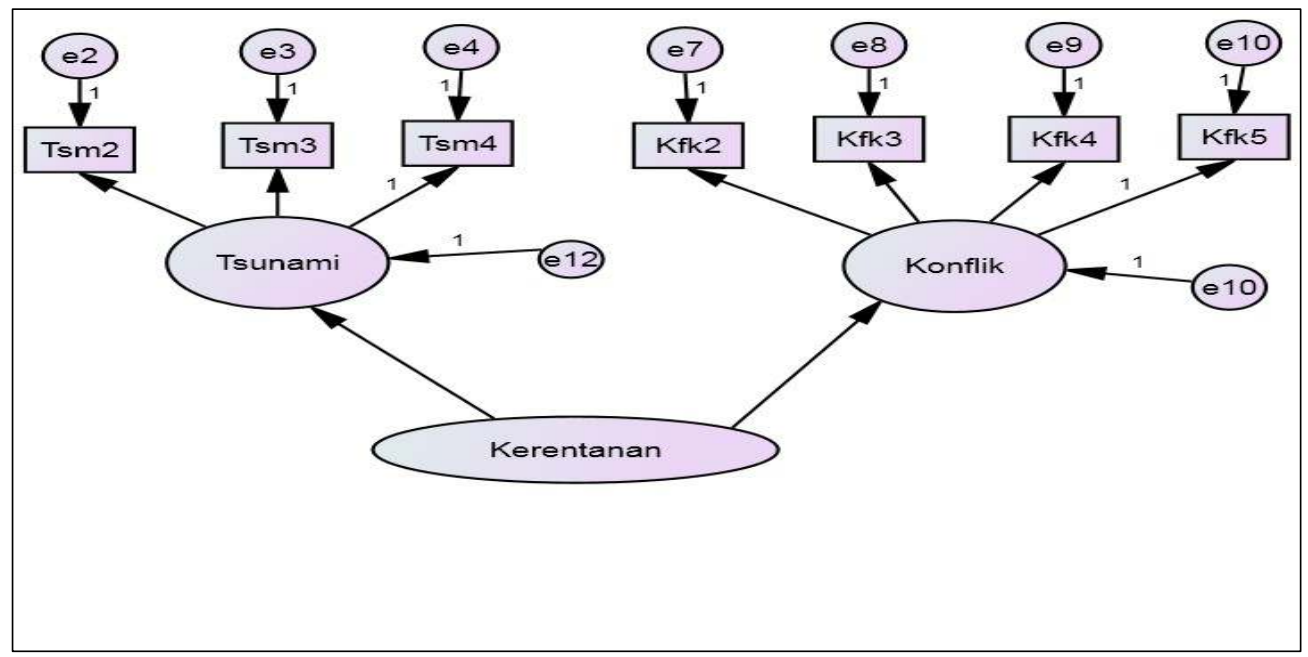

Gambar 5. Model 2 pengesahan faktor kerentanan

Hasil analisis model 2 mendapatkan

nilai $\chi^{2}(\mathrm{CMIN})$ telah berkurang kepada 27.404 dengan darjah kebebasan 13 dan nilai kebarangkalian 0.011. Selain itu, nilai kesepadanan yang lain juga sudah memenuhi nilai yang disarankan. Nilai 
$\mathrm{CMIN} / \mathrm{DF}=2.108$ yaitu melebihi 1 dan kurang daripada 5 seperti yang disarankan, Nilai GFI $=0.986$, AGFI $=0.970$, NFI $=0.978, \mathrm{RFI}=0.965$, IFI $=0.989$, TLI $=$ 0.981 , CFI $=0.988$ yaitu melebihi 0.90 seperti yang disarankan, dan nilai RMSEA $=0.045$ yang kurang daripada 0.1 seperti yang disarankan. Hasil ini menunjukkan kesepadanan data dengan model yang di hipotesis adalah baik. Semua indikator dapat menjelaskan semua konstruk yang ada. Tabel 2 menunjukkan nilai regresi dan terlihat semua nilai muatan faktor (factor loading ) menunjukkan angka di atas 0.5 dan semua nilai $P$ (probability) adalah signifikan pada $\alpha=1$. Jika $p>0.05$ menunjukkan bahwa tidak ada hubungan antara tsunami atau konflik dengan faktor kerentanan. Hal ini menunjukkan bahawa semua indikator dapat menjelaskan konstruk yang ada. Oleh sebab itu Model 2 ini dijadikan sebagai model akhir untuk variabel faktor kerentanan

Tabel 2. Nilai Regresi (Regression Weights) indikator faktor kerentanan

\begin{tabular}{|c|c|c|c|c|c|c|c|}
\hline \multicolumn{3}{|c|}{ Indikator } & Koefisien & S.E. & C.R. & $\mathbf{P}$ & Loading factor \\
\hline Tsunami & $<---$ & kerentanan & .127 & .061 & 2.096 & .036 & .632 \\
\hline Konflik & $<---$ & kerentanan & 1.632 & .226 & 7.237 & $* * *$ & .510 \\
\hline tsm4 & $<---$ & Tsunami & 1.015 & .066 & 15.365 & $* * *$ & .710 \\
\hline tsm3 & $<---$ & Tsunami & .986 & .064 & 15.365 & $* * *$ & .721 \\
\hline tsm2 & $<---$ & Tsunami & 1.199 & .078 & 15.471 & $* * *$ & .902 \\
\hline kfk5 & $<---$ & Konflik & .958 & .060 & 16.075 & $* * *$ & .885 \\
\hline kfk4 & $<---$ & Konflik & .626 & .052 & 11.988 & $* * *$ & .537 \\
\hline kfk3 & $<---$ & Konflik & 1.043 & .065 & 16.075 & $* * *$ & .815 \\
\hline kfk2 & $<---$ & Konflik & .431 & .054 & 7.986 & $* * *$ & .501 \\
\hline
\end{tabular}

Sumber : Hasil analisis data dengan kaedah SEM

Hasil analisis ini menunjukkan bahwa kejadian tsunami dan konflik mempunyai hubungan dengan kerentanan, di mana tsunami dan konflik dapat menyebabkan terjadinya kerentanan. Hasil penelitian ini berbeda dengan hasil kajian Sahri, M. at al. (2011) yang menggunakan indikator perubahan musim, konflik antara nelayan, dan perubahan harga bahan bakar minyak (BBM) untuk faktor kerentanan. Di mana ketiga indikator ini dapat menjelaskan konstruk kerentanan dan berpengaruh langsung kepada hasil kehidupan. Hasil kajiannya menemukan bahwa ketiga indikator tersebut dapat menjelaskan faktor kerentanan. Tito (2013) berpendapat bahawa tingkat kerentanan pada petani yang paling tinggi adalah pada aset alam karena bencana banjir yang menenggelami tanah pertanian dan aset keuangan karena kekurangan modal usaha. Roslina, K. (2009) pula menyatakan bahwa musim hujan dan kemarau, faktor biologi dan teknik seperti penyakit tanaman, kurang pengetahuan, dan faktor sosial ekonomi seperti kenaikan harga input yang tinggi merupakan masalah kerentanan. Mukherjee (2001) pula menyatakan dalam kajiannya bahwa faktor kerentanan sangat berpengaruh kepada hasil kehidupan masyarakat. Evy Lisna at al. (2012) menambahkan bahwa untuk mengatasi kerentanan diperlukan peningkatan pelayanan dan fungsi sosial masyarakat dalam proses politik termasuk kaum wanita selain juga meningkatkan akses sumberdaya.

\section{KESIMPULAN}

Berdasarkan hasil penelitian yang telah dilakukan dengan menggunakan analisis pengesahan faktor kerentanan petani adalah model yang kedua merupakan model yang menunjukkan kesepadanan data dengan model yang dihipotesis adalah baik. Oleh karena itu Model 2 ini dijadikan 
sebagai model akhir untuk konstruk faktor kerentanan petani. Hal ini juga menunjukkan bahwa semua nilai muatan faktor (factor loading) memiliki angka di atas 0.5 dan semua nilai $P$ (probability) adalah signifikan pada $\alpha=1 \%$. Nilai $P$ adalah 0.000 yang jauh di bawah 0.05 yang menunjukkan bahawa semua indikator dapat menjelaskan konstruk yang ada.

\section{DAFTAR PUSTAKA}

Andriani, D. 2013. Pengenalan Structural Equation Modeling. http://magisterakutansi. blogspot. com/2012/11/pengenalan-structuralequation-modeling.html (diakses 10 Oktober 2012).

Burt, R.S. 1992. Excerpt from The Sosial Structure of Competition, in Structure Holes: The Social Structure of Competition. Cambridge, MA and London: Harvard University. In Elinor Ostrom and T.K. Ahn. 2003. Foundation of Social Capital. Publishing Limited.

DFID. 1999. Sustainable Livelihoods Guidance Sheets. www.livelihoods.org/ info/info guidancesheets.html\#6 (15 Oktober 2012).

Jensen, H.G.P., Pender, J., Damon, A., and Shipper, R. 2006. Rural Development Policies and Sustainable Land Use in the Hillside Areas of Honduras : A Quantitative Livelihood Approach. Research Report 147. International Food Policy Research Institute (IFRI): Washington.

Joreskog, K. G. \& Sorbom, D. 1993. LISREL S: Structural equation modeling with the SIMPLIS command language. Hillsdale, NJ: Erlbaum.

Hair, J., Black, W., Babin, B., Anderson, R., \& Tatham, R. (2006). Multivariate data analysis (6th ed.).

Uppersaddle River, N.J.Pearson Prentice Hall.

Moser, C. 1998. The Asset Vulnerability Framework: Reassesing Urban Poverty Reduction Strategies. World Development 26 (1) :1-19.

Murray, Janet and Ferguson, M. 2001. Women in Transition Out of Poverty. Toronto: Women and Economic Development Consortium. January. http://www.cdnwomen.org/eng/3/3h .asp. (19 November 2011)

Mitlin, D. 2002. Reducing Urban Poverty:

Some Lessons From Experience Satterthwaite: 173 -

179.http://www.manchester.ac.uk/re search/diana.mitlin/ publications .pdf (12 januari 2012)

Naning, W. 2011. Analisis Keragaan Petani Apel Melalui Pendekatan Sustainable Livelihood (Studi Kasus Di Desa Poncokusumo, Kecamatan Poncokusumo, Kabupaten Malang). Skripsi. Universiti Brawijaya, Malang.

Rahmah Ismail . 2003. Ekonomi Pembangunan. Isu Sumber Manusia, Bangi: Penerbit UKM.

Rakodi, C. 1999. A Capital Asset Framework for Analyzing Household Lifelihood Strategies. Development Policy Review 17(3) : $15-42$

Roslina, K. $2009 . \quad$ Pembangunan Akuakultur di Kedah : Analisis Impak Ekonomi, Sosial dan Alam Sekitar Menggunakan Pendekatan Kehidupan Lestari. Tesis Phd Institut Alam Sekitar dan Pembangunan, Universiti Kebangsaan Malaysia.

Sahri, M., Mashudi dan Sukoharsono, E.G. 2011. Analisis Faktor-Faktor yang Mempengaruhi Aksesibilitas Sosial Ekonomi Nelayan Kecil di Jawa Timur. Jurnal Ilmu Sosial, 18(1), 4355.

Santoso, Singgih. 2011. Structural Equation Modeling (SEM), Konsep dan Aplikasi dengan AMOS 18. PT. 
Elex Media Komputindo, Kompas Gramedia. Jakarta.

Salvestrin, H. 2006. Sustainable Livelihoods Approach And Community Development In Practice In Engineering Organizations.

http://epress.lib.uts.edu.au/scholarly works/bitstream/handle/2100/301/0 2WholeThesis.pdf (10 Disember 2012)

Tito, I. S. 2013. Identifikasi Tingkat Kerentanan Petani di Kawasan
Rawan Genangan Banjir Melalui Pendekatan Sustainable Livelihoods (Studi Kasus: Desa Bulung Cangkring Kecamatan Jekulo Kabupaten Kudus). Skripsi, UNS.

UNDP. 2010. Aceh Partnerships for Economic Development (APED): Annual Progress Report 2009. Disusun bagi Biro untuk Pencegahan dan Pemulihan Krisis (BCPR). $\quad$ Februari 2010. 